\title{
Determination of Wounding Potential of Guns KNOWN FROM CHILDHOOD - BLOWPIPE AND SLINGSHOT
}

\author{
MARTIN FICEK, LUDVÍK JUŘÍČEK, MICHAL GRACLA, ZDENĚK \\ MALÁNÍK \& MICHAELA MIKULIČOVÁ
}

Abstract: This paper deal with the comparison of relative wounding potential of guns, which we know from childhood, specifically blowpipe and slingshot. Many people played with these guns in childhood without knowing how dangerous these guns are. Because this area has not been examined enough, this paper focuses on it. The relative wounding potential is examined through an experimental method. This method is indirect and includes shooting to the replacement material, which was gelatine with a concentration of $20 \%$. Using a high-speed camera, the course of missiles in the target, from penetration to stopping, is recorded. The volume of the temporary cavity is determined by image analysis, and subsequently, the relative wounding potential is calculated. Other monitored parameters are the depth of penetration of the projectile and the impact velocity of the projectile. Then, it is possible to determine the transmitted kinetic energy of the projectile. The results should help to assess the dangers of these "children's" weapons and alert society to their risks. They can also serve to experts in the field of ballistics and forensic expertise.

Key words: blowpipe, slingshot, relative wounding potential, substitute material, $20 \%$ gelatine.
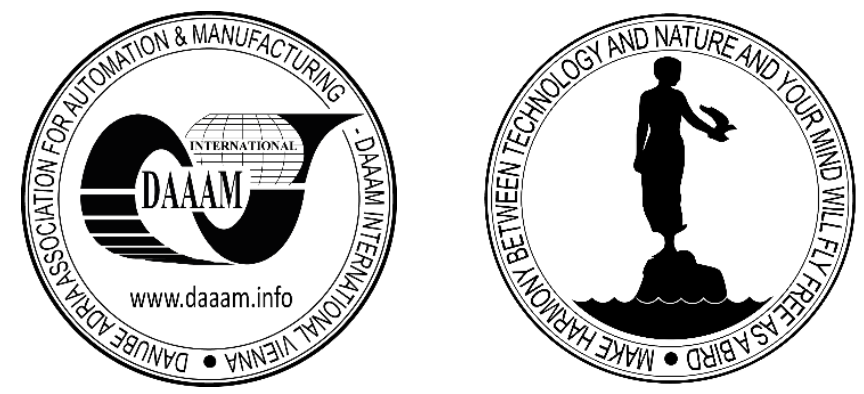

Authors' data: Martin Ficek*, Ludvík Juříček, Michal Gracla, Zdeněk Maláník \& Michaela Mikuličová, Tomas Bata University in Zlín, nám. T. G. Masaryka 5555, 760 01 Zlín, CZ, *ficek@utb.cz*

This Publication has to be referred as: Ficek, M[artin]; Juricek, L[udvik]; Gracla, M[ichal]; Malanik, Z[denek] \& Mikulicova, M[ichaela] (2020). Determination of Wounding Potential of Guns Known from Childhood - Blowpipe and Slingshot, Chapter 19 in DAAAM International Scientific Book 2020, pp.227-236, B. Katalinic (Ed.), Published by DAAAM International, ISBN 978-3-902734-27-3, ISSN 17269687, Vienna, Austria

DOI: $10.2507 /$ daaam.scibook.2020.19 
Ficek, M.; Juricek, L.; Gracla, M.; Malanik, Z. \& Mikulicova, M.: Determination of...

\section{Introduction}

Possibly every boy had a weapon, blowpipe, slingshot, bow, airsoft gun, air rifle, etc. in his youth. Probably the most common weapons were slingshots and blowguns because they could be made of materials that could be found at home. It was enough to have a suitably shaped stick and rubber to make the slingshot. The blowpipe used to be made of a pen casing. In childhood, our parents told us to not play with these weapons because they were dangerous. To answer the question of how much and whether these weapons are dangerous, research is needed.

As far as we know, no one has ever dealt with this particular area, i.e. the wounding potential of a slingshot or a blowpipe, on a scientific basis. In general, several authors deal with wounding ballistics, such as Ludvík Juříček [1,2,3,], Beat P. Kneubuehl [4,5,6], Malcolm J Dodd [7], Steven Manners [8], Di Maio [ 9] or Zvi Rosenberg [10].

A related area to the researched intention is to determine the wounding potential of low-power weapons such as air rifles, expansion weapons, bows, crossbows or airsoft weapons $[11,12,13,14,15,16]$. However, no one has dealt directly with the area of determining the wounding potential of a blowpipe and a slingshot - the authors have not been able to find any article discussing the wounding potential of a blowpipe or a slingshot from the available databases. Hence, it is necessary to research this area in detail.

In this paper, we examine already modern and professionally made weapons, i.e. a blowpipe and a slingshot with appropriate ammunition. Our research is based on knowledge of wounding ballistics, which is generally used. We investigate the wounding potential of a slingshot and a blowpipe, and we provide their comparison. The results can serve to experts in the field of ballistics and forensic expertise.

\section{Methods}

The method, used in this article, is based on an experiment, which consists of shooting from a slingshot and a blowpipe into a replacement material. The depth of the shot in the replacement material was monitored, and the trajectory of the missiles through the material was recorded using a high-speed camera. Furthermore, the velocity of the missiles on impact was measured using ballistic gates.

The experimental workplace was as follows: the shooting took place at a distance of $2 \mathrm{~m}$. Ballistic gates CALDWELL CHRONOGRAPH with a maximum deviation of $+/-0.25 \%$ (60 cm spacing) were placed $15 \mathrm{~cm}$ in front of the replacement material. The muzzle of the weapon was placed $125 \mathrm{~cm}$ from the ballistic gates.

Ballistic gelatine, with a concentration of $20 \%$, was chosen as a replacement material. Gelatin of this concentration is close to the muscles of the human body with its physical properties (see Table 1). 


\begin{tabular}{|c|c|c|c|c|c|c|}
\hline \multirow{2}{*}{ Material } & $\mathbf{t}$ & $\mathbf{\rho}$ & $\mathbf{K}$ & $\mathbf{n}$ & $\mathbf{v}$ & $\mathbf{c}$ \\
\cline { 2 - 7 } & ${ }^{\circ} \mathrm{C}$ & {$\left[\mathrm{kg} \cdot \mathrm{m}^{-3}\right]$} & {$\left[\mathrm{Pa}^{-1}\right]$} & {$[\mathrm{Pa} \cdot \mathrm{s}]$} & {$\left[\mathrm{m}^{2} \cdot \mathrm{s}^{-1}\right]$} & {$\left[\mathrm{m} \cdot \mathrm{s}^{-1}\right]$} \\
\hline $\begin{array}{c}20 \% \\
\text { Gelatine }\end{array}$ & 20 & 1060 & $3,8 \cdot 10^{-10}$ & $1,0 \cdot 10^{2}$ & 0,1 & 1567 \\
\hline
\end{tabular}

Tab. 1. Properties of ballistic gelatine with a concentration of $20 \%$.

Where $\mathrm{t}$ - temperature, $\rho$ - density, $\mathrm{K}$ - compressibility, $\eta$ - dynamic viscosity, $\mathrm{v}$ - kinetic viscosity, $\mathrm{c}$ - speed of sound. The dynamic viscosity was measured at $30{ }^{\circ} \mathrm{C}$ as it increases strongly with decreasing temperature. A blowpipe (Fig. No. 1) and a slingshot (Fig. No. 2) were used.

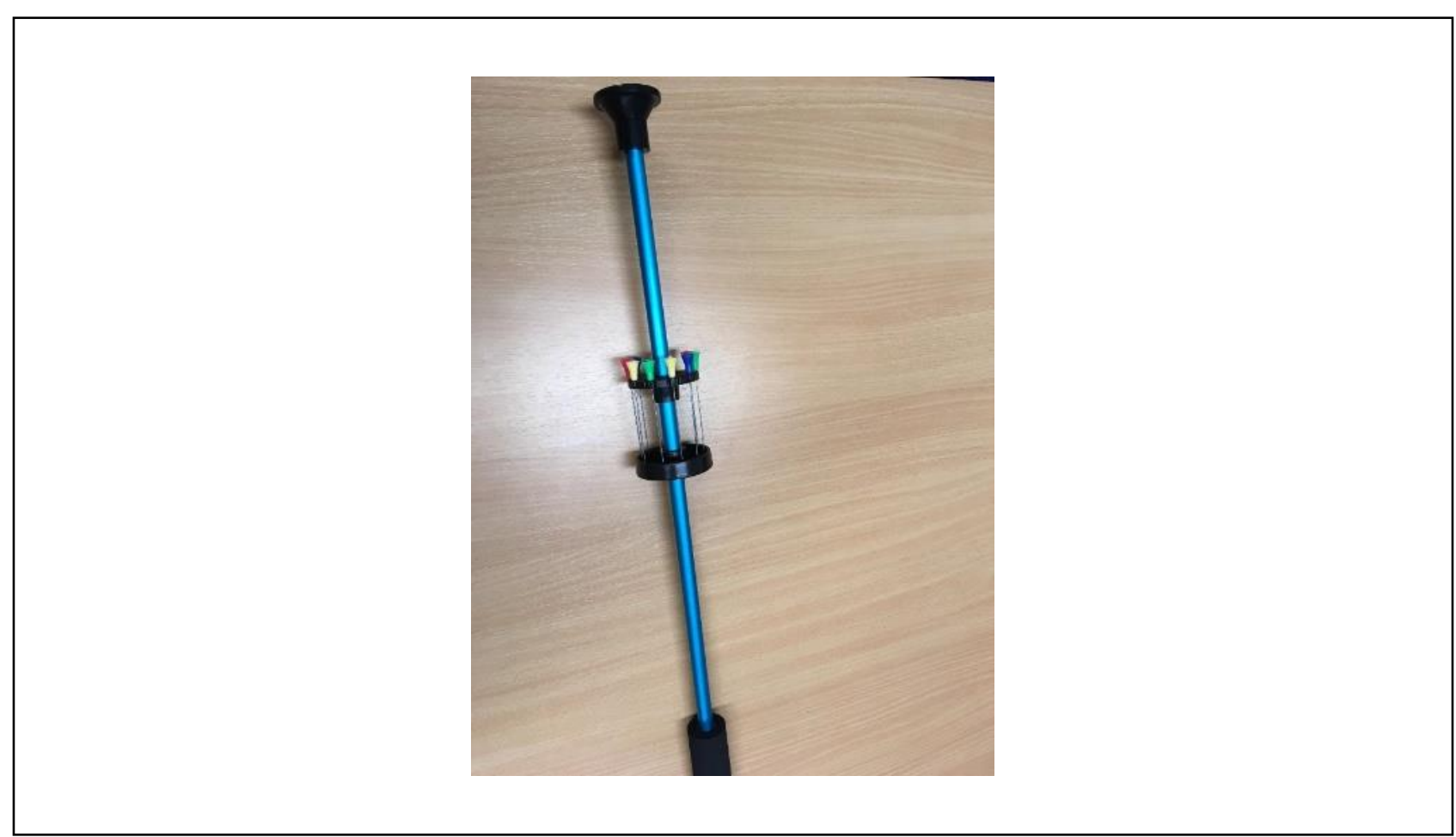

Fig. 1. Blowpipe.

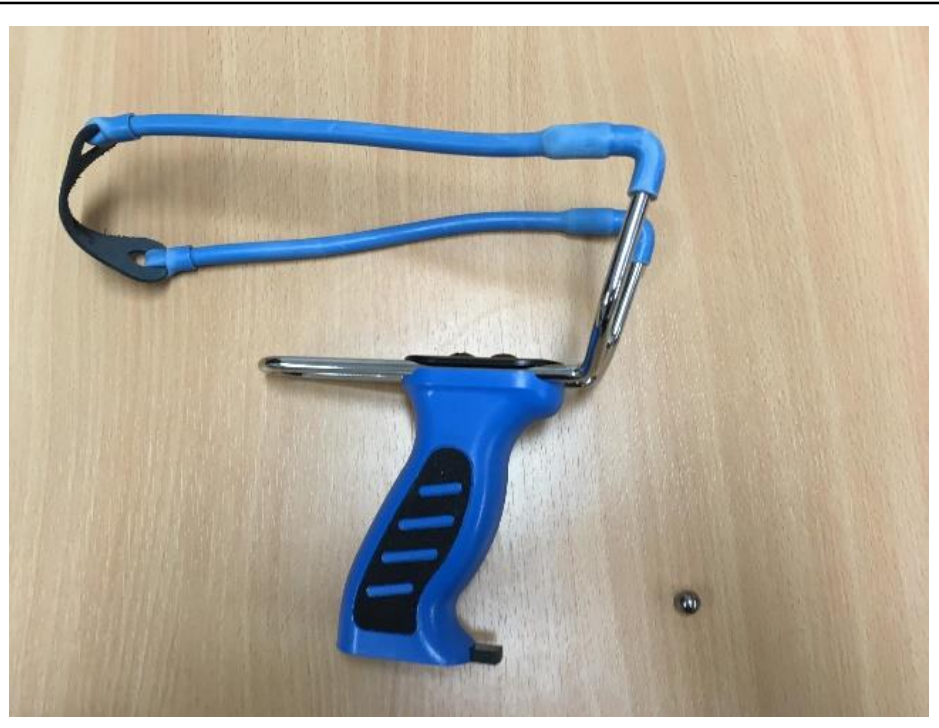

Fig. 2. Slingshot with a ball. 
Ficek, M.; Juricek, L.; Gracla, M.; Malanik, Z. \& Mikulicova, M.: Determination of...

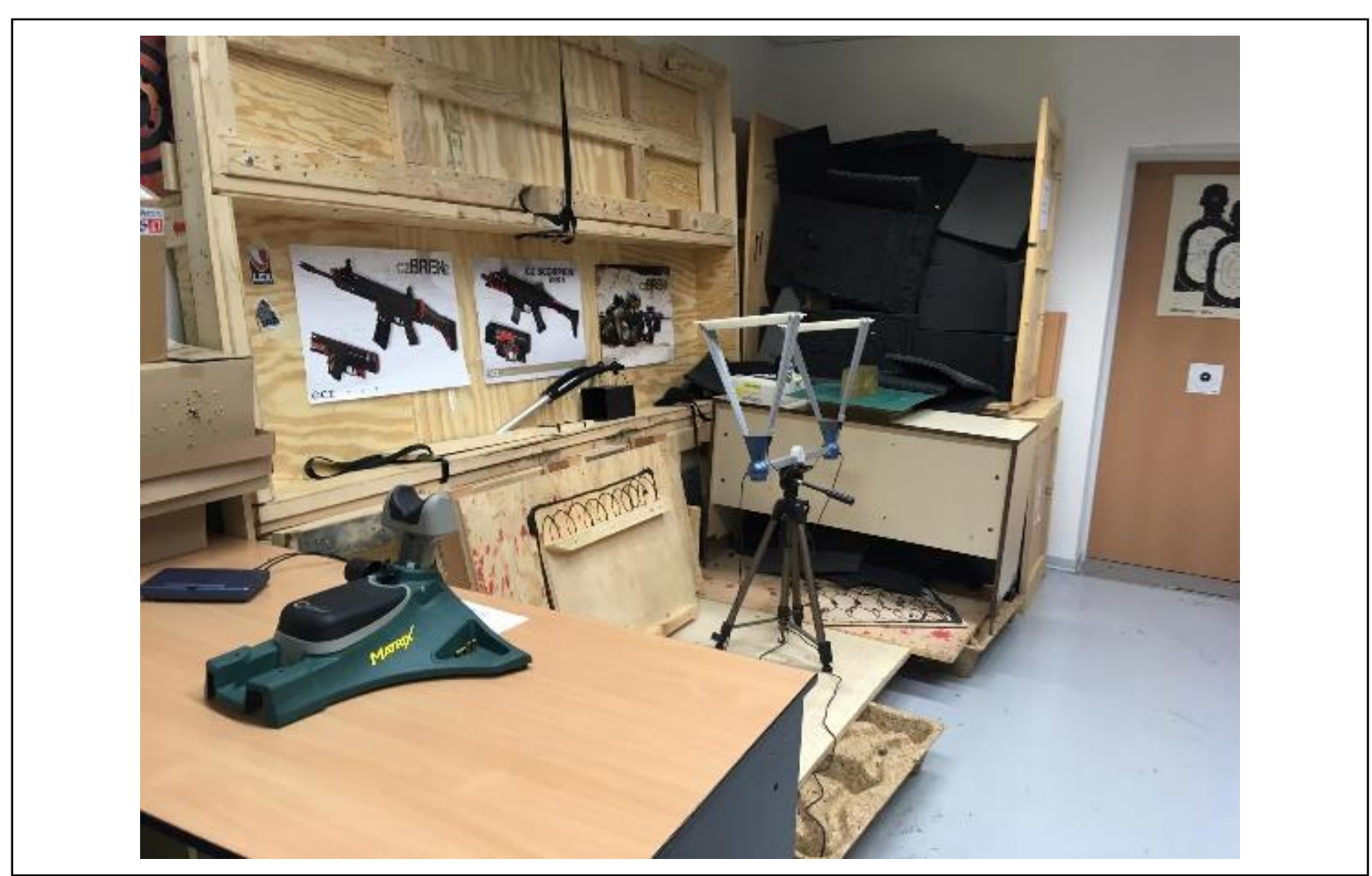

Fig. 3. Slingshot with a ball.

Each weapon was shot ten times. The results of this experiment are described in the following chapter.

\section{Results}

Directly measured values were: $\mathrm{v}_{\mathrm{I}}$ - impact velocity, $\mathrm{s}_{\mathrm{D}}$ - shot depth. The $\mathrm{V}_{\mathrm{TC}}$ - the volume of the temporary cavity and $\mathrm{w}_{\mathrm{TC}}$ - the maximum width of the temporary cavity were determined by the image analysis of the recordings from the high-speed camera. Using the formula $E_{k}=\frac{1}{2} m v^{2}$, the $\mathrm{E}_{\mathrm{I}}$ impact kinetic energy was calculated. $\mathrm{E}_{\mathrm{I}}$ is identical to $E_{k}$. RWP - relative wounding potential is calculated based on the relationship $R W P=\frac{E_{I}}{V_{T C}}$ and expresses the amount of transmitted kinetic energy that the projectile needs to create $1 \mathrm{~cm}^{3}$ of the volume of the cavity of the fire channel in the replacement material. RWP is a quantity inverted to the coefficient of proportionality $\mu\left[\mathrm{cm}^{3} . \mathrm{J}^{-1}\right]$, which was used by M. L. Fackler to define the resistance of soap blocks to the penetration of a projectile.

\begin{tabular}{|c|c|c|c|c|c|c|}
\hline \multirow{2}{*}{ Blowpipe } & $\begin{array}{c}\text { Impact } \\
\text { velocity }\end{array}$ & $\begin{array}{c}\text { Shot } \\
\text { depth }\end{array}$ & $\begin{array}{c}\text { Volume of } \\
\text { temporary } \\
\text { cavity }\end{array}$ & $\begin{array}{c}\text { Maximum } \\
\text { width of } \\
\text { temporary } \\
\text { cavity }\end{array}$ & $\begin{array}{c}\text { Impact } \\
\text { kinetic } \\
\text { energy }\end{array}$ & $\begin{array}{c}\text { Relative } \\
\text { wounding } \\
\text { potential }\end{array}$ \\
\cline { 2 - 7 } & $\mathrm{m} \cdot \mathrm{s}^{-1}$ & $\mathrm{~mm}$ & $\mathrm{~mm}^{3}$ & $\mathrm{~mm}$ & $\mathrm{~J}$ & $\mathrm{~J} \cdot \mathrm{mm}^{-3}$ \\
\hline 1. missile & 32,8 & 56 & 139,1 & 12,0 & 0,43 & 0,0031 \\
\hline 2. missile & 31,5 & 68 & 142,3 & 12,2 & 0,40 & 0,0028 \\
\hline
\end{tabular}




\begin{tabular}{|l|l|l|l|l|l|l|}
\hline 3. missile & 35,0 & 57 & 139,9 & 11,9 & 0,49 & 0,0035 \\
\hline 4. missile & 32,1 & 54 & 137,2 & 11,8 & 0,41 & 0,0030 \\
\hline 5. missile & 36,8 & 69 & 143,1 & 12,3 & 0,54 & 0,0038 \\
\hline 6. missile & 35,1 & 65 & 141,8 & 12,1 & 0,49 & 0,0035 \\
\hline 7. missile & 34,9 & 64 & 141,8 & 12,1 & 0,49 & 0,0034 \\
\hline 8. missile & 33,4 & 59 & 140,3 & 12,1 & 0,45 & 0,0032 \\
\hline 9. missile & 35,7 & 66 & 142,0 & 12,1 & 0,51 & 0,0036 \\
\hline 10. missile & 32,2 & 55 & 138,5 & 11,9 & 0,41 & 0,0030 \\
\hline
\end{tabular}

Tab. 2. Values measured and calculated for the blowpipe.

The variance in velocity in the case of a blowpipe is affected by how powerfully we blow into it. Interestingly, the depth of the shot is considerable despite the low speed and the weight of the dart $(0.8 \mathrm{~g})$. The maximum width occurs at the entrance. It is caused by a plastic seal at the end of the dart. As a result, the data is so similar. As can be seen, the relative wounding potential is almost negligible.

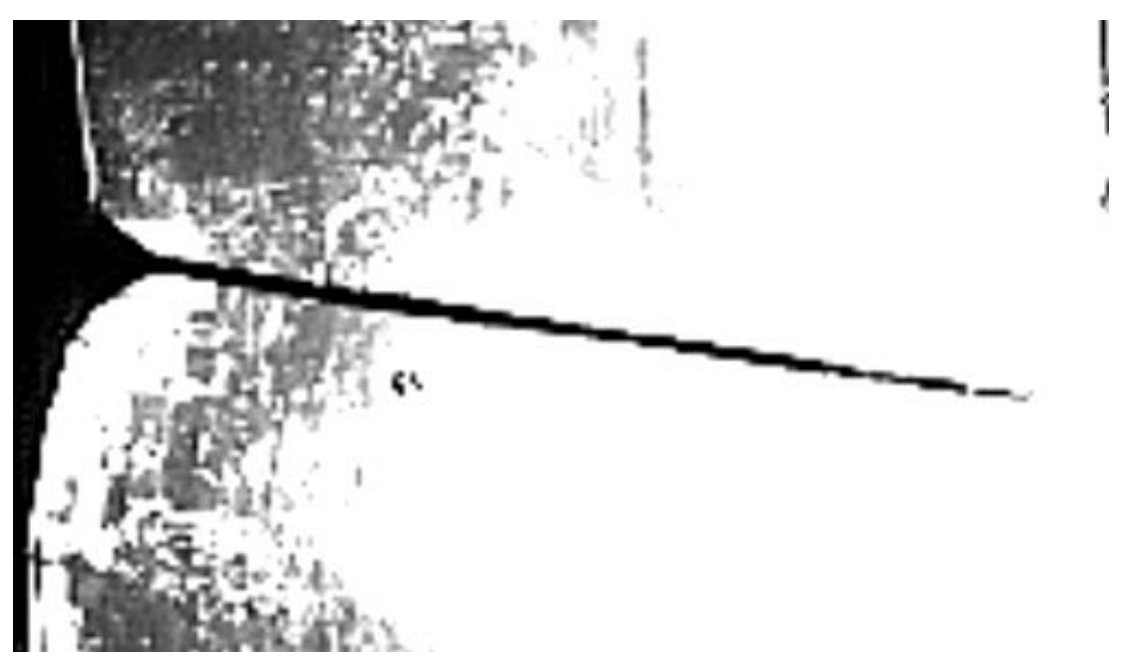

Fig. 4. A maximal dimension of the temporary cavity.

\begin{tabular}{|c|c|c|c|c|c|c|}
\hline \multirow{2}{*}{ Slingshot } & $\begin{array}{c}\text { Impact } \\
\text { velocity }\end{array}$ & $\begin{array}{c}\text { Shot } \\
\text { depth }\end{array}$ & $\begin{array}{c}\text { Volume of } \\
\text { temporary } \\
\text { cavity }\end{array}$ & $\begin{array}{c}\text { Maximum } \\
\text { width of } \\
\text { temporary } \\
\text { cavity }\end{array}$ & $\begin{array}{c}\text { Impact } \\
\text { kinetic } \\
\text { energy }\end{array}$ & $\begin{array}{c}\text { Relative } \\
\text { wounding } \\
\text { potential }\end{array}$ \\
\cline { 2 - 6 } & $\mathrm{m} \cdot \mathrm{s}^{-1}$ & $\mathrm{~mm}$ & $\mathrm{~mm}^{3}$ & $\mathrm{~mm}$ & $\mathrm{~J}$ & $\mathrm{~J} \cdot \mathrm{mm}^{-3}$ \\
\hline 1. missile & 28,5 & 13 & 761,8 & 12,1 & 1,42 & 0,0019 \\
\hline 2. missile & 29,6 & 14 & 799,6 & 14.6 & 1,53 & 0,0019 \\
\hline 3. missile & 38,3 & 29 & 1051,9 & 22,2 & 2,57 & 0,0024 \\
\hline 4. missile & 41,0 & 31 & 1072,8 & 26.7 & 2,94 & 0,0027 \\
\hline 5. missile & 40,6 & 30 & 1064,3 & 24,4 & 2,88 & 0,0027 \\
\hline 6. missile & 37,1 & 28 & 1002,5 & 21.9 & 2,41 & 0,0024 \\
\hline 7. missile & 31,4 & 20 & 816,0 & 15,3 & 1,73 & 0,0021 \\
\hline 8. missile & 30,2 & 19 & 801,7 & 15.7 & 1,60 & 0,0020 \\
\hline 9. missile & 29,0 & 19 & 846,2 & 14,5 & 1,47 & 0,0017 \\
\hline 10. missile & 33,9 & 23 & 946,7 & 19.0 & 2,01 & 0,0021 \\
\hline
\end{tabular}

Tab. 3. Values measured and calculated for the slingshot. 
Ficek, M.; Juricek, L.; Gracla, M.; Malanik, Z. \& Mikulicova, M.: Determination of...

The variance in velocities for a slingshot is affected by how much we tighten the sling rubber. The depth of the shot is proportional to the speed and weight of the bullet (3.5 g). The maximum width occurs at the entrance. As can be seen, the relative wounding potential is almost negligible; however, the data on the temporary cavity is significant. Specifically, the dimension of the temporary cavity is relatively large compared to a blowpipe. The size of the temporary cavity was more challenging to determine. As the ball passed through the block of the replacement material, two temporary cavities were created. The first one at the inlet (Fig. 5) began to close when the ball penetrated to a greater depth of the replacement material. The second one began to form at the same moment (Fig. 6), and this formation lasted until the ball stopped in the block of the replacement material (Fig. 7). The resulting size of the volume of the temporary cavity is thus the sum of the maximum volumes of these temporary cavities.

In contrast to firearms, it is complicated to provide similar values of energy or velocity of missiles with these weapons. This is because these weapons use the human force transmitted by the missiles. In the case of a blowpipe, the force of exhalation is transmitted. In the case of a slingshot, the force, with which the rubber is stretched, is transmitted. Therefore, the values are on a relatively large scale.

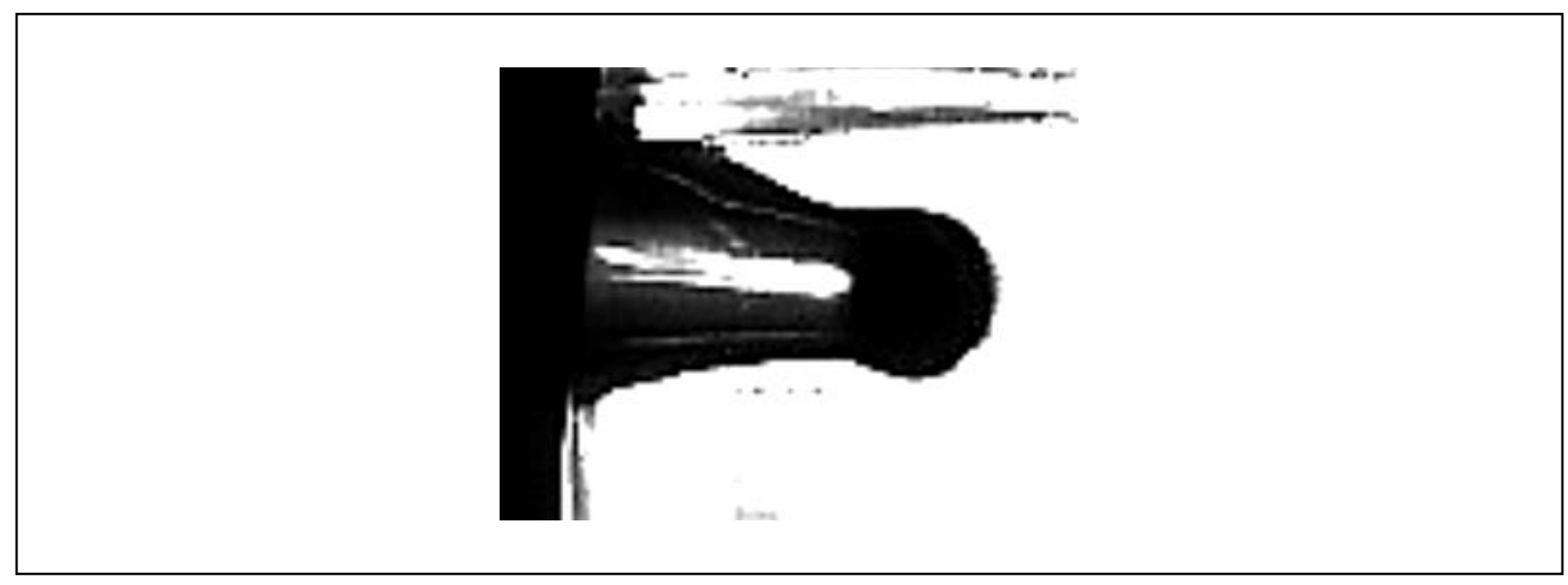

Fig. 5. The temporary cavity at the entrance of the ball fired from the slingshot into the replacement material.

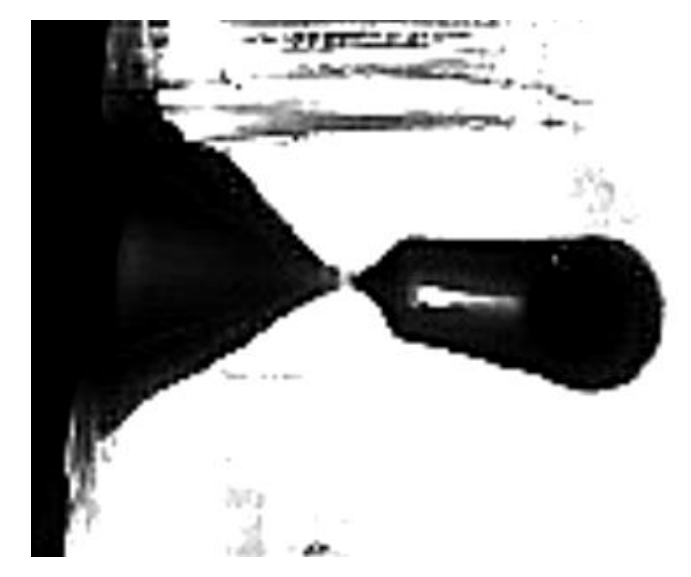

Fig. 6. Formation of the second temporary cavity and the beginning of the closure of the first one. 


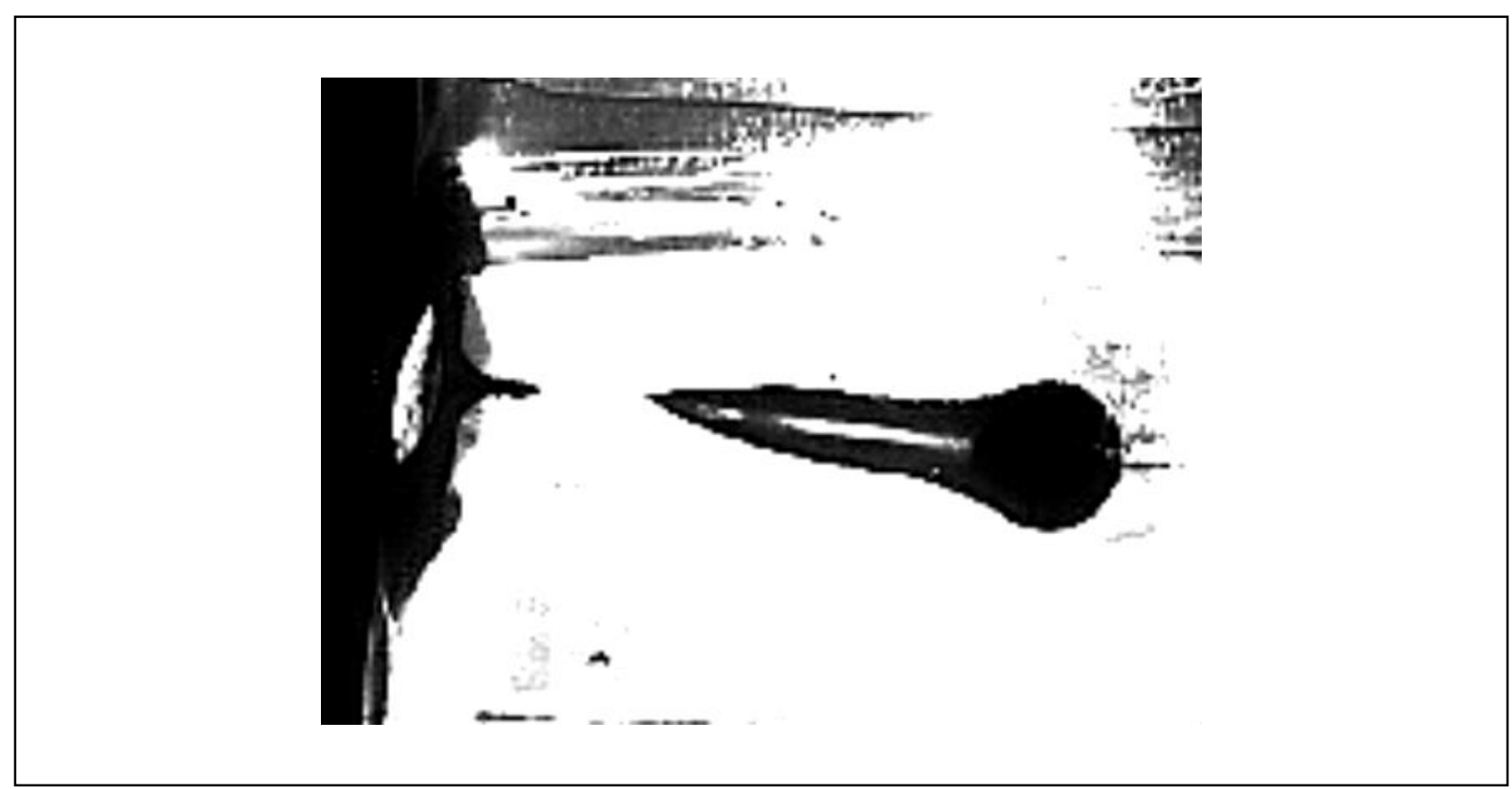

Fig. 7. Second temporary cavity with the maximum volume.
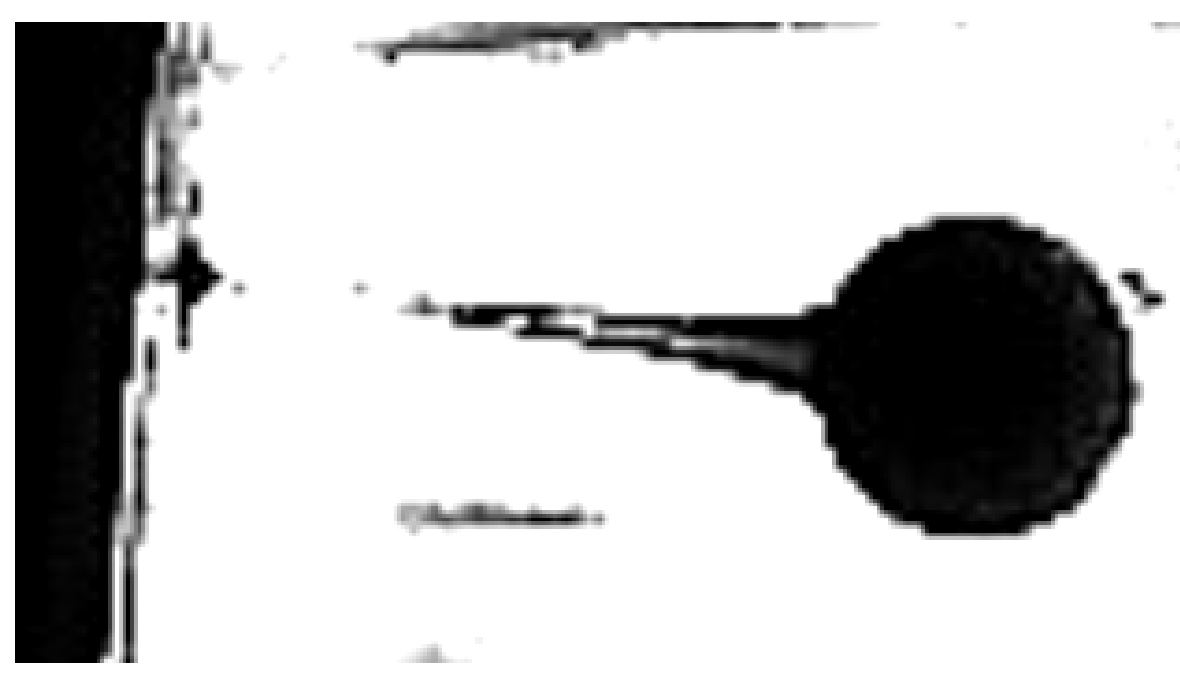

Fig. 8. The permanent cavity of the slingshot.

\begin{tabular}{|l|c|c|c|c|c|c|}
\hline \multirow{2}{*}{ Weapon } & $\begin{array}{c}\text { Impact } \\
\text { velocity }\end{array}$ & $\begin{array}{c}\text { Shot } \\
\text { depth }\end{array}$ & $\begin{array}{c}\text { Volume of } \\
\text { temporary } \\
\text { cavity }\end{array}$ & $\begin{array}{c}\text { Maximum } \\
\text { width of } \\
\text { temporary } \\
\text { cavity }\end{array}$ & $\begin{array}{c}\text { Impact } \\
\text { kinetic } \\
\text { energy }\end{array}$ & $\begin{array}{c}\text { Relative } \\
\text { wounding } \\
\text { potential }\end{array}$ \\
\cline { 2 - 7 } & \multicolumn{7}{|c|}{$\mathrm{m} \cdot \mathrm{s}^{-1}$} & $\mathrm{~mm}$ & $\mathrm{~mm}^{3}$ & $\mathrm{~m}$ Arithmetic mean \\
\hline Blowpipe & 33,95 & 61,3 & 140,6 & 12,05 & $\mathrm{~J}$ & $\mathrm{~J} \cdot \mathrm{mm}^{-3}$ \\
\hline Slingshot & 33,96 & 22,6 & 916,35 & 18,64 & 2,06 & 0,0033 \\
\hline
\end{tabular}

Tab. 4. Values measured and calculated for the slingshot. 
Ficek, M.; Juricek, L.; Gracla, M.; Malanik, Z. \& Mikulicova, M.: Determination of...

Table 4 clearly shows the average values for measured or calculated parameters. Interestingly, the average speed is almost the same for both weapons. As might be expected, a blowpipe that shoots sharp thin darts has a far greater depth of shot than a steel ball fired from a slingshot. However, a significant difference can be observed in the case of the volume of the temporary cavity. The dart passes almost without the formation of a temporary cavity, which arises practically only at the end of the dart, where a plastic stop of the arrow strikes or partially penetrates the replacement material.

On the other hand, the ball penetrates during the entire path and causes the formation of the temporary cavity. Similarly to the dart, the maximum width of the temporary cavity is at the point of penetration. As can be seen, the transmitted kinetic energy is more than four times larger in the slingshot than in the blowpipe. The relative wounding potential of the projectiles is almost the same (the difference is nearly negligible); however, the blowpipe has a slightly higher wounding potential, which is given by the relationship of the amount of energy per unit volume.

The authors of the article would rather choose the criterion of proportionality coefficient (PC), which shows the amount of volume that arises per unit of energy with the calculation $P C=\frac{V_{T C}}{E_{I}}\left[\mathrm{~cm}^{3} \cdot J^{-1}\right]$, where $\mathrm{V}_{\mathrm{TC}}$ is the volume of the firing channel (temporary cavity) and $\mathrm{E}_{\mathrm{I}}$ is the impact energy (in this case identical to the kinetic energy at impact). According to the authors, this criterion expresses the wounding potential of the projectile adequately and serve to compare individual weapons better.

For this criterion, $\mathrm{PC}$ has an average value of $307 \mathrm{~mm}^{3} \cdot \mathrm{J}^{-1}$ for the blowpipe and 463.8 $\mathrm{mm}^{3} \cdot \mathrm{J}^{-1}$ for the slingshot. In the case of the blowpipe, a PC of $307 \mathrm{~mm} 3 \cdot \mathrm{J}-1$ would be generated by transmitting $1 \mathrm{~J}$ of kinetic energy (impact). In the case of the slingshot, a $\mathrm{PC}$ of $463.8 \mathrm{~mm} 3 \cdot \mathrm{J}-1$ would be produced.

\begin{tabular}{|c|c|}
\hline \multirow{2}{*}{ Weapon } & Proportionality coefficient (PC) \\
\cline { 2 - 2 } & {$\left[\mathrm{mm}^{3} \cdot \mathrm{J}^{-1}\right]$} \\
\hline Blowpipe & 307,00 \\
\hline Slingshot & 463,80 \\
\hline
\end{tabular}

Tab. 5. Values measured and calculated for the slingshot.

\section{Conclusion}

This article focused on determining the wounding potential of weapons known from childhood, namely the blowpipe and the slingshot. Data were obtained from the experiment. From these data, the wounding potential of weapons can be determined. The most important criteria are the proportionality coefficient, the volume of the temporary cavity and the impact (kinetic) energy. The slingshot has higher values in all these parameters. From this, it can be stated that the slingshot has a higher wounding potential in the muscles. Although the blowpipe penetrates deeper, it practically does not cause injuries, while the slingshot penetrates only a few centimetres of muscle, but causes more serious injuries. 
It should be admitted that this paper deals with the study of the wounding potential for living tissue, namely for muscles that are replaced by physically similar material (20\% gelatine). It can be assumed that if the skin cover were also presented in the experiment, the ball fired from the slingshot would not penetrate the replacement material, and there would be a vertical shot, or the muscle damage would be considerably reduced. This assumption is confirmed by the experience of authors from childhood. It can also be assumed that with the addition of a skin cover, the depth of the shot from the blowpipe would be significantly reduced; however, the dart would still penetrate the muscles. It can be stated that, in real life, these weapons do not pose a significant risk; however, the specific risk is a situation where the projectile would be aimed, for example, at the eyes. Although the title of the article states that these weapons are from childhood, it must be said that they should be placed in the hands of children only under the supervision of prudent and careful parents. The findings of this article should contribute to the education of the public; moreover, they should help experts in the field of forensic expertise or ballistics.

\section{Acknowledgements}

This research was supported by the Internal Grant Agency of Tomas Bata University in Zlín under the project No. IGA/FAI/2020/003 and by the Institute of Safety Engineering of Faculty of Applied Informatics.

\section{References}

Juříček, L. (2015). Ranivý Potenciál Malorážových Střel A Jeho Hodnocení, Key Publishing, Isbn 978-80-7418-222-8, Ostrava.

Juříček, L. (2017). Ranivá Balistika: Technické, Soudnělékařské A Kriminalistické Aspekty, Key Publishing, Isbn 9788020616500, Ostrava.

Juříček, L., Moravanský, N. (2015). Ballistic Simulation On Direct Effects Of Small Arms Projectiles On Human Bone Tissue. Polish Journal Of Health And Fitness 1. 2015(1), 72-82.

Kneubuehl, B., P. (2004). Balistika: Střely, Přesnost Střelby, Účinek, Naše Vojsko, Isbn 80-206-0749-8, Praha.

Kneubuehl, B., P., Coupland R., M., Rothchild M., A., Thali, M., J., Coupland R., M., (2011). Wound Ballistics. Transl. Of The Rev. 3. German Ed, Springer, Isbn 978-3642203-565, Dordrecht.

Kneubuehl, B., P. Et Al., 2008. Wundballistik: Grundlagen Und Anwendungen. 3. Springer-Verlag Berlin Heidelberg, Isbn 978-3-540-79008-2, Berlin.

Dodd, M., J., Byrne, K., (2006). Terminal Ballistics: A Text And Atlas Of Gunshot Wounds, Boca Raton, Fl, Isbn 978-084-9335-778.

Manners, S., (2002). Wound Ballistics, On: Gutter Press, Isbn 978-1896356419, Toronto.

Di Maio, V., J., M., (1999). Gunshot Wounds: Practical Aspects Of Firearms, Ballistics, And Forensic Techniques. 2nd Ed. Boca Raton: Crc Press, Isbn 08-4938163-0. 
Ficek, M.; Juricek, L.; Gracla, M.; Malanik, Z. \& Mikulicova, M.: Determination of...

Rosenberg, Z., Dekel E., (2016). Terminal Ballistics., Ny: Springer Berlin Heidelberg, Isbn 978-9811003936, New York.

Ficek, M., Maláník, Z., Mikuličová, M. And Gracla, M. (2019) Influence Of The Shooting Distance On The Depth Of Penetration Of The Bullet Into The Replacement Material For Air Gun Weapons. In: 30 Daaam International Symposium On Intelligent Manufacturing And Automation Available From: Https://Www.Scopus.Com/Inward/Record.Uri?Eid=2-S2.085077912393\&Doi=10.2507\%2f30th.Daaam.Proceedings.091\&Partnerid=40\&Md5= $1 \mathrm{cf} 1 \mathrm{c} 836 \mathrm{f0cd} 2326255 \mathrm{e} 3 \mathrm{~d} 51 \mathrm{ad} 9 \mathrm{c} 0 \mathrm{c} 83$ Scopus.

Doi 10.2507/30th.Daaam.Proceedings.091.

Mikulicova, Michaela Et Al., (2017). Comparison Of Depth Of Incomplete Penetration For Different Types Of Pellets For Shooting Weapon Of Category D. In: 2017 International Conference On Military Technologies (Icmt). Ieee, S. 66-69. Doi: 10.1109/Miltechs.2017.7988732. Isbn 978-1-5090-5666-8. Available From: Http://Ieeexplore.Ieee.Org/Document/7988732/

Gracla, M., Chocholatý A., Maláník, Z., (2017). Analýza Ranivého Účinku Základních Zbraní Kategorie D. In: Sborník Příspěvků Konference Expert Forensic Science Brno 2017 (Exfos 2017): Xxvi. Mezinárodní Vědecká Konference Soudního Inženýrství. Vysoké Učení Technické V Brně, Ústav Soudního Inženýrství, Purkyňova 464/118, 61200 Brno, S. 327-336 [Cit. 2017-01-31]. Isbn 978-80-214-5459-0, Brno. Available From: Www.Exfos.Cz

Ogunc, G., I., Et Al., (2013). The Wounding Potential And Legal Situations Of Air Guns - Experimental Study. Australian Journal Of Forensic Sciences. 46(1), 39-52. Doi: 10.1080/00450618.2013.789078. Issn 0045-0618. Available From: Http://Www.Tandfonline.Com/Doi/Abs/10.1080/00450618.2013.789078

Smith, W., D., F., (1985). Air Rifle Ammunition And Its Influence On Wounding Potential. Archive Of Emergenci Medicine. 25-29.

Bakovic, M., Et Al., (2014). Shot Through The Heart - Firepower And Potential Lethality Of Air Weapons. Journal Of Forensic Sciences. 59(6), 1658-1661. Doi: 10.1111/1556-4029.12486. Issn 00221198 Available From: Http://Doi.Wiley.Com/10.1111/1556-4029.12486 